\title{
David Oliver: Getting serious about prevention
}

\author{
David Oliver consultant in geriatrics and acute general medicine
}

Berkshire

It's hard to attend any conference or read any report on health service reform without prevention of ill health featuring prominently. What might once have seemed a radical proposition is now an orthodoxy-but people commenting on health system redesign still advocate a greater focus on prevention and early intervention as if it's a revelation, even for those in government.

The arguments advanced for prevention contain two broad elements. Firstly, our health services are still too centred on responding to ill health, especially acute illness in excessively hospital based models. We therefore need a shift of resources and approaches to ensure that more people remain well for longer (primary prevention) or are supported to self manage any long term condition to reduce complications, slow progression, and maximise wellbeing (secondary prevention).

Secondly, a shift towards prevention requires interventions throughout the whole life course and a focus on reducing health inequalities, as the antecedents of ill health are cumulative and synergistic. Conventional medical care is only a small part of the picture, and many of the wider determinants of physical and mental health lie in wider communities, universal public services, and private and voluntary sectors. Allied to this should be a focus on maximising the health assets of citizens rather than on disease and health deficits.

Such arguments have been made in numerous high profile reports, including those by Derek Wanless for the Treasury, ${ }^{1}$ the House of Lords committee on NHS sustainability, ${ }^{2}$ and the University of Birmingham policy commission. ${ }^{3}$ Government policy documents, going back over several parliaments, are full of them.

In the face of these entirely sensible recommendations, the recent policy response in England has been to move public health from the NHS to local government, notionally to tackle the wider determinants of health and join up public health with other services. ${ }^{4}$ But local government budgets have been slashed since $2010^{5}$ : public health funding fell by around $£ 200 \mathrm{~m}$ under the 2010-15 coalition government. ${ }^{6}$ A recent King's Fund analysis showed a further $5 \%$ cut in public health funding since then and predicted another $£ 88 \mathrm{~m}$ of public health cuts for 2018 that will affect sexual health, smoking cessation, and drug and alcohol interventions. ${ }^{7}$
These cuts also affect transport, leisure, social services, and funding for the voluntary organisations, day centres, and libraries that help people retain independence and stay connected to the community. Meanwhile, changes to welfare, far from helping the "just about managing," have done little to help wellbeing or lessen inequalities for people living with poor health or disability. ${ }^{8}$

Politicians in office are far more likely to be judged on how health services perform right now, for the sickest people

We've failed to implement a simple policy on minimum unit alcohol pricing despite clear evidence of benefit. ${ }^{9}$ And the government's recent childhood obesity strategy was neutered. ${ }^{10}$ It can be difficult to "sell" major investment in prevention and public health—especially when primary and secondary care services are severely underfunded and where any "return on investment" dividend may not be seen for years. ${ }^{112}$ Politicians in office are far more likely to be judged on how health services perform right now, for the sickest people.

From now on, every time I hear people using policy rhetoric to make the case for prevention, I'll ask them, "So, what policies and funding do we have in place to back the paper talk and make it happen?"

Competing interests: See www.bmj.com/about-bmj/freelancecontributors/david-oliver.

Provenance and peer review: Commissioned; not externally peer reviewed.

Follow David on Twitter: @mancunianmedic

Wanless D. Securing Our Future Health: Taking a long-term view—the Wanless review. April 2002. http://webarchive.nationalarchives.gov.uk/+/http://www.hm-treasury.gov.uk/ consult_wanless_index.htm.

2 Select Committee on the Long-term Sustainability of the NHS. The long-term sustainability of the NHS and adult social care. 5 April 2017. https://publications.parliament.uk/pa/ Id201617/ldselect//dnhssus/151/151.pdf.

3 Birmingham Policy Commission. Healthy ageing in the 21st century: the best is yet to come. 2014. https://www.birmingham.ac.uk/Documents/research/policycommission/ healthy-ageing/Healthy-Ageing-Policy-Commission-Report.pdf.

4 Department of Health. The new public health role of local authorities. Oct 2012. https:// www.gov.uk/government/uploads/system/uploads/attachment_data/file/213009/Publichealth-role-of-local-authorities-factsheet.pdf. 
5 Full Fact. Local authorities' budgets are roughly 26\% lower since 2010. 29 Jan 2017. https://fullfact.org/economy/local-authorities-budgets/.

6 Buck D. King's Fund. Local government public health budgets: a time for turning? 19 Aug 2016. https://www.kingsfund.org.uk/blog/2016/08/local-government-public-health-budgets. King's Fund. Big cuts planned to public health budgets. 12 July 2017. https://www. kingsfund.org.uk/press/press-releases/big-cuts-planned-public-health-budgets.

8 Syal R. Benefit mismanagement hurting sick and disabled, watchdog says. Guardian 27 Feb 2014. https://www.theguardian.com/society/2014/feb/27/benefit-mismanagementhurting-sick-and-disabled-atos-capita.

9 Royal College of Physicians. What the RCP thinks about alcohol. 1 Feb 2018. https:// www.rcplondon.ac.uk/projects/outputs/what-rcp-thinks-about-alcohol.
10 Boseley S. Childhood obesity: UK's "inexcusable" strategy is wasted opportunity, say experts. Guardian 18 Aug 2016. https://www.theguardian.com/society/2016/aug/18/ childhood-obesity-strategy-wasted-opportunity-campaigners.

11 King's Fund. Making the case for public health interventions. https://www.kingsfund.org uk/audio-video/public-health-spending-roi.

12 Newton J, Ferguson B. Making the economic case for prevention. Public Health England. 6 Sept 2017. https://publichealthmatters.blog.gov.uk/2017/09/06/making-the-economiccase-for-prevention/.

Published by the BMJ Publishing Group Limited. For permission to use (where not already granted under a licence) please go to http://group.bmj.com/group/rights-licensing/ permissions 